$\begin{array}{ll} & \text { Etnográfica } \\ \text { etnográfica } & \text { Revista do Centro em Rede de Investigação em }\end{array}$

Antropologia

vol. $14(1) \mid 2010$

Vol. $14(1)$

\title{
Manuela Cunha e Luís Cunha (orgs.), Intersecções Ibéricas: Margens, Passagens e Fronteiras
}

\author{
Irene Rodrigues
}

\section{OpenEdition}

\section{Journals}

\section{Edição electrónica}

URL: https://journals.openedition.org/etnografica/372

DOI: 10.4000/etnografica.372

ISSN: 2182-2891

\section{Editora}

Centro em Rede de Investigação em Antropologia

\section{Edição impressa}

Data de publição: 1 fevereiro 2010

Paginação: 204-206

ISSN: 0873-6561

\section{Refêrencia eletrónica}

Irene Rodrigues, «Manuela Cunha e Luís Cunha (orgs.), Intersecções Ibéricas: Margens, Passagens e Fronteiras», Etnográfica [Online], vol. 14 (1) | 2010, posto online no dia 21 outubro 2011, consultado o 12 fevereiro 2022. URL: http://journals.openedition.org/etnografica/372 ; DOl: https://doi.org/10.4000/ etnografica.372

Este documento foi criado de forma automática no dia 12 fevereiro 2022

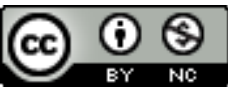

Etnográfica is licensed under a Creative Commons Attribution-NonCommercial 4.0 International License. 


\title{
Manuela Cunha e Luís Cunha (orgs.), Intersecções Ibéricas: Margens, Passagens e Fronteiras
}

\author{
Irene Rodrigues
}

\section{REFERÊNCIA}

Manuela Cunha e Luís Cunha (orgs.), Intersecções Ibéricas: Margens, Passagens e Fronteiras, Lisboa, $90^{\circ}$ Editora, 380 páginas.

1 Esta obra colectiva é o resultado das discussões e debates ligados à ideia de fronteira, temperada pelas noções de margem e de passagem, que fizeram pulsar o 4.ำ Encontro Ibérico de Antropólogos em 2007. O volume integra 20 trabalhos de antropólogos espanhóis e portugueses com uma diversificação de contribuições que, embora partindo todas elas do mote que é a ideia de fronteira, a desenvolvem e instrumentalizam de modos e em contextos muito diferentes, desde trabalhos no âmbito mais estrito da definição clássica de fronteira, como o território imediatamente a seguir à raia que separa duas nações, até à abordagem do próprio corpo como forma de demarcação de uma fronteira. Não obstante esta diversidade, os organizadores mostraram grande perícia no modo coerente e acertado como arrumaram os contributos.

2 A sua diversificação constitui simultaneamente desafio e estímulo para pensar a ideia de fronteira, que é assumida na introdução como conceito central, mas entendida num vasto espectro, desde a frontier à boundary. Para além de um cruzamento de fronteiras conceptuais, no seu todo este colectivo também estimula o atravessamento de fronteiras etnográficas e nacionais, não se restringindo a terrenos portugueses e espanhóis. Sem querer estabelecer qualquer fronteira entre os contributos por nacionalidade, fica uma nota para assinalar a ausência, neste volume, de trabalhos de 
antropólogos espanhóis em terrenos portugueses, o que seria de esperar no contexto de um encontro ibérico sobre fronteiras.

3 Os trabalhos estão arrumados em quatro partes que se caracterizam pela predominância de uma orientação de desenvolvimento do tema principal. Será impossível nestas escassas linhas fazer justiça aos trabalhos aqui assinados por tantos autores diferentes em 380 páginas. Optei por apresentar o volume por partes, elas próprias bastante coerentes, destacando o contributo principal de cada texto para o diálogo colectivo, e dar a oportunidade ao leitor de vislumbrar cada um dos contributos e compreender ao mesmo tempo a riqueza do diálogo desenvolvido em torno da ideia de fronteira. $O$ interesse dos textos do volume vai muito além dos interessados apenas nas temáticas da fronteira e dos limites em antropologia.

4 Na primeira parte, os textos exploram o significado de fronteira nos seus sentidos político, social e cultural, com frequentes diálogos interdisciplinares com a história e com a geopolítica. Os textos de Luís Cunha e de Ana Rita Moreira tratam da representação da fronteira e do seu significado político. Luís Cunha demonstra a ambiguidade envolta na definição dos limites na fronteira luso-espanhola e o processo de cristalização de uma fronteira política com influências profundas na identidade nacional. Num regresso à actualidade, o autor demonstra como a abolição dos controlos aduaneiros transformou o uso da fronteira, mas não a eliminou, permanecendo um recurso para a memória e o turismo. 0 trabalho de Ana Rita Moreira trata da fronteira europeia e do modo como a localização geográfica de Portugal em relação à Europa, pela proximidade de África, foi interpretada no período de surgimento do nacionalismo português de modo a dar sentido à ambiguidade portuguesa entre a Europa do progresso e a "orientalidade" africana. Para além do trabalho de Luís Cunha, que remete para a história da fronteira, os trabalhos de Humberto Martins e de Paula Godinho também apelam à memória e ao passado, focando o modo como as populações de um e de outro lado da fronteira norte luso-espanhola sempre viveram neste atravessamento, mesmo contra a vontade das autoridades políticas, questionando totalmente a ideia da ocorrência de uma grande mudança e de uma maior proximidade entre as populações de um e de outro lado da fronteira apenas depois da recente abertura. Também sobre o atravessamento da raia entre Espanha e Portugal, mas na zona Sul da península, Rita Gomes Faria demonstra que, mais do que os portugueses e os espanhóis, são os marroquinos que vêem e vivem a fronteira entre Portugal e Espanha como um espaço de continuidade, talvez por não haver sobre ela uma memória de barreira do passado. Este primeiro conjunto termina com um texto mais clássico, que resvala para um idioma indianista. $O$ trabalho de Manuel João Magalhães trata de marcas deixadas por uma fronteira passada num contexto pós-colonial em Goa. $\mathrm{O}$ autor mostra de modo muito interessante como a memória de uma barreira política passada produziu contestação e luta pelo poder, influenciando a organização dos limites sociais e, sobretudo, simbólicos.

5 A segunda parte do livro trata principalmente dos processos de construção, constituição e exibição de património, sublinhando-se a marginalidade de alguns locais e o processo da sua constituição como património. Matilde Córdoba Azcárate, sobre Taramundi nas Astúrias, e Joan Frigolé, a propósito dos Pirenéus catalães, sublinham a ambiguidade do desenvolvimento económico gerado pela manutenção de um ideal de ruralidade e de proximidade com a natureza. É nesta linha de pensamento que JeanYves Durand também questiona os processos de certificação dos produtos de 
artesanato, que implicam pensar e definir os limites que do que é o artesanato, por referência a outros produtos, e os colocam à mercê dos desafios do formalismo legalista. Os efeitos e os limites da patrimonialização, mas em meio museológico, são tratados nos textos de Ascensión Brânano Cid e João Alpuim Botelho, ao questionarem as práticas expositivas, a política cultural e as tendências de coisificação da cultura. Num registo de diálogo diferente dos anteriores, entre a etnografia e a produção de memória, situa-se o artigo sobre o Campus do Instituto Superior Técnico na Alameda, em Lisboa, com uma muito interessante narrativa sobre as mudanças na apropriação do espaço, as relações de poder e a memória num local de produção de conhecimento tecnológico.

6 Na terceira parte, as ideias de limite e de fronteira ganham contornos mais sociais que nos textos anteriores. Os temas são etnograficamente muito diversificados, mas fala-se sobretudo de marginalidade, tal como faz Garcia Garcia ao analisar o duplo estigma enfrentado pelos mineiros pré--reformados que transportam para o período de préreforma os estigmas associados a um trabalho poluente e arriscado, agora interpretados em termos morais. Destaque também para o único texto assumidamente metodológico do colectivo, do antropólogo Jaume Franquesa, que debate abertamente os problemas de investigação e de enfoque associados à definição de um bairro como unidade de análise privilegiada numa investigação, nomeadamente em relação à sua delimitação. É também através do estudo de bairros e dos processos de mercantilização e do direito à habitação em Berlim que Irene Sabaté Muriel procura expor as formas de contestação de fronteiras e a marginalização social. Seguindo com o tema da contestação política no espaço público e direitos sobre o território, Susana Naroztky "etnografou" e analisou uma manifestação contra a construção de uma fábrica de gás em Ferrolterra. A politização da marginalidade foi também observada por Josep Cucó Giner na transição do discurso do Partido Comunista Espanhol da defesa dos interesses do operariado para a marginalização e para a pobreza.

7 Os três últimos capítulos integram a quarta parte e estão mais próximos das relações entre a natureza e a cultura. José Maria Uribe trata a diferença cultural no âmbito do sistema de saúde e, de um modo mais amplo, no contexto dos sistemas de segurança social. A demarcação de limites através da alimentação demonstra bem a intersecção entre as fronteiras da natureza e da cultura no texto de Virgínia Calado. Essas fronteiras são também cruzadas por Manuela Ivone Cunha e Jean-Yves Durand em torno das preocupações com a imunização do corpo, a acção sobre ele e os limites da acção do Estado e do conhecimento.

Interseções Ibéricas comprova a criatividade e a dinâmica da antropologia ibérica, num diálogo e aprofundamento conceptual criativo, com textos que merecem ser lidos para além dos limites "naturais" da fronteira e do limite. 


\section{AUTORES}

IRENE RODRIGUES

ICS - Universidade de Lisboa 